\title{
[Letter to the Editor] \\ Many commercial hot-start polymerases demonstrate activity prior to thermal activation
}

The polymerase chain reaction (PCR) is an enzymatic technique for the in vitro synthesis of targeted nucleic acid regions (1), and it is an integral method in most aspects of molecular biology and genetics. PCR relies on thermally stable DNA polymerase to synthesize DNA by adding nucleotides complementary to those on a single-stranded template. By repeated cycling through 3 key temperatures (usually $95^{\circ} \mathrm{C}, \sim 60^{\circ} \mathrm{C}$, and $72^{\circ} \mathrm{C}$ ), exponential amplification of a target template is obtained (2).
Many molecular applications, including forensics and clinical diagnostics, are highly reliant on $\mathrm{PCR}$, requiring consistent, accurate, and repeatable assays $(3,4)$. In such instances, the generation of misleading or false results may have profound implications and, therefore, a high level of analytical accuracy is required.

The development of hot-start DNA polymerases was a significant PCR innovation. Hot-start polymerases remain inactive until the reaction is heated to a temperature at which oligonucleotide primers can no longer anneal to the DNA template (5). This prevents non-specific amplification and primerdimer formation, and allows reaction mixes to be prepared at room temperature without the negative impact of spurious polymerase activity (6-10).

During establishment of an assay for measuring telomere length, we observed that several commercial hot-start polymerases mediated formation of primer-dimers (11). Here,

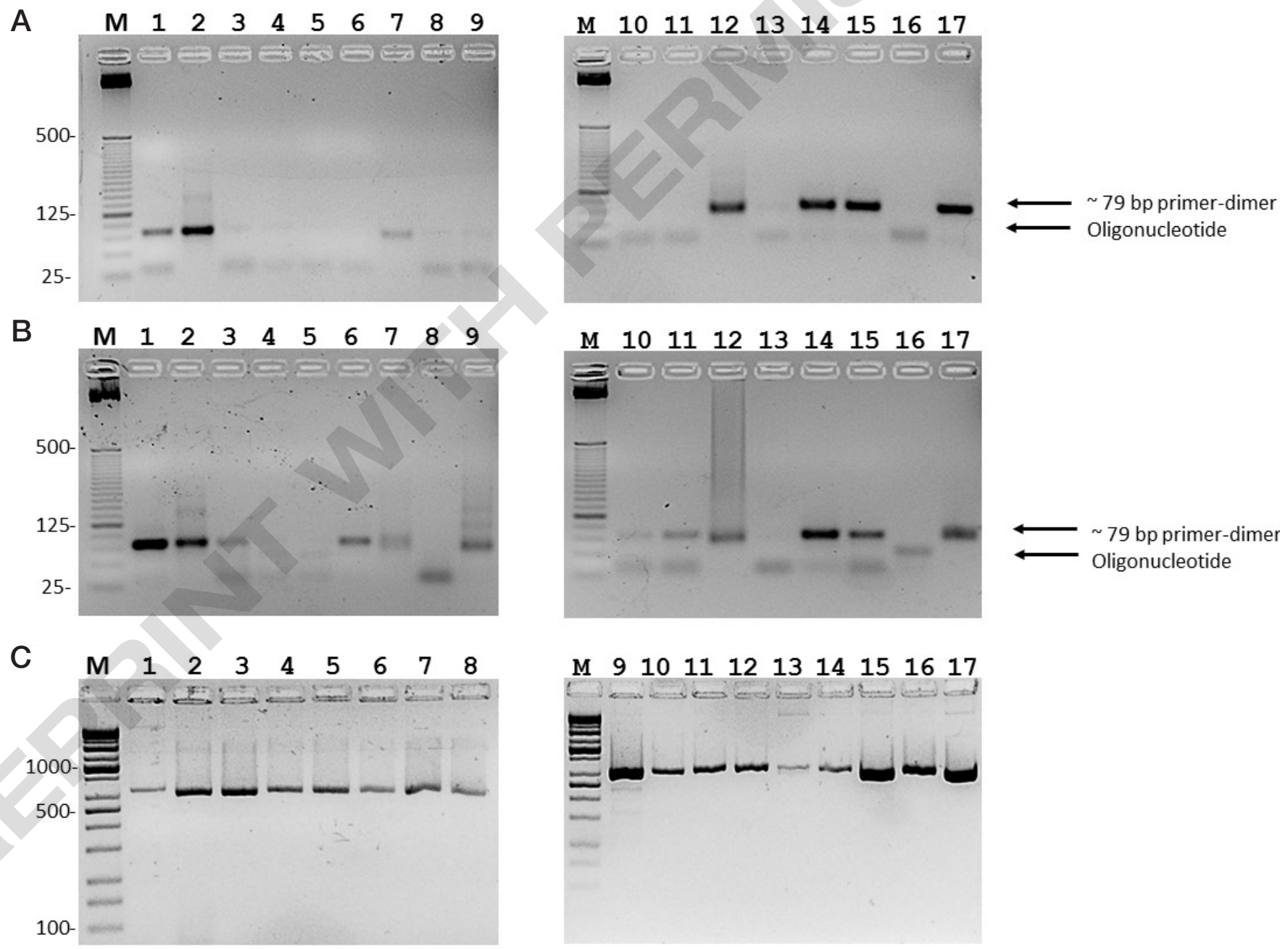

Figure 1. Assay for polymerase activity prior to thermal activation. Polymerase activity assay performed using (A) Primer Set 1 and (B) Primer Set 2. Lanes 1-17 represent analysis of 17 different hot-start polymerase enzymes; M denotes 25-bp DNA ladder (Invitrogen, Carlsbad, CA). (C) Positive amplification control for activity of the hot-start polymerase enzymes used above; M denotes Universal DNA 150-bp ladder (KAPABIOSYSTEMS, Wilmington, MA). 
we expand these observations and describe a simple method for detecting polymerase activity prior to the initial heat denaturation step. In this assay, 2 different primer pairs (Table 1) are used, and each primer pair can form a 3-bp overlap capable of annealing at room temperature. If a DNA polymerase extends either pair of primers prior to thermal activation, an 79-bp primerdimer will be formed which acts as the template for amplification in subsequent cycles (Figure 1). However, an effective hot-start enzyme will not produce a primer-dimer, as the enzyme activation and subsequent PCR cycling temperatures are higher than the annealing temperature of the 3-bp overlap. No genomic DNA template is required in this simple assay format.

PCR was carried out in a Mastercycler pro thermal cycler (Eppendorf, Stevenage, UK). A total reaction volume of $30 \mu$ l containing $1 \times$ buffer, $\mathrm{MgCl}_{2}$, dNTPs, hot-start polymerase, and primers (IDT, Singapore) was used, at the concentrations recommended by the manufacturers. A robust amplicon was used as a positive control for polymerase activity (Table 1) in a reaction containing $\sim 30 \mathrm{ng}$ of human genomic DNA (Figure 1C). The reactions were prepared at room temperature, and hot-start polymerase activity was assayed using touchdown PCR (12). The initial denaturation time and extension temperature were adjusted according to the enzyme suppliers' specifications and are specified in Table 2. Cycling conditions consisted of denaturation at $95^{\circ} \mathrm{C}$ for $15 \mathrm{~s}$, annealing for $15 \mathrm{~s}$, and extension for $45 \mathrm{~s}$. The initial annealing temperature was $65^{\circ} \mathrm{C}$, and this was decreased by $1^{\circ} \mathrm{C}$ per cycle for 10 cycles, followed by 25 cycles at $55^{\circ} \mathrm{C}$. A final extension was performed for $5 \mathrm{~min}$.

In total, 17 hot-start DNA polymerase enzymes (Table 2) were assayed for activity prior to thermal denaturation using 2 primer pairs (Primer Sets 1 and 2), in addition to a positive control primer pair to confirm the overall polymerase activity in each preparation. The presence of a primer-dimer at $\sim 79$ bp indicates activity of the hot-start enzyme prior to thermal activation. The absence of a primer-dimer indicates that the enzyme was only active after thermal activation, as would be expected for a

Table 1. Oligonucleotide sequences used.

\begin{tabular}{|c|c|c|}
\hline Primer name & Primer sequence: $5^{\circ}$ to $3^{\circ}$ & $\mathrm{T}_{\mathrm{m}}^{* * *}$ \\
\hline Primer Set $1 \mathrm{~F}^{*}$ & ATTATCGTAGATGCTAGCTGGTATGGTACGTAATGAATTCTA & $69.49^{\circ} \mathrm{C}$ \\
\hline Primer Set $1 \mathrm{R}^{*}$ & TTATACATCGGACCAGCATATTCATGTCATCTAGGAAGATAG & $71.73^{\circ} \mathrm{C}$ \\
\hline Primer Set 2F (telg) & ACACTAAGGTTTGGGTTTGGGTTTGGGTTTGGGTTAGTGT & $76.80^{\circ} \mathrm{C}$ \\
\hline Primer Set 2R (telc) & TGTTAGGTATCCCTATCCCTATCCCTATCCCTATCCCTAACA & $73.05^{\circ} \mathrm{C}$ \\
\hline Positive control PF** & GTGCCCCGCTAAACTTCAGA & $61.09^{\circ} \mathrm{C}$ \\
\hline Positive control PR ** & TGTGGGACAGTTTCAGTAACCT & $57.15^{\circ} \mathrm{C}$ \\
\hline \multicolumn{3}{|c|}{$\begin{array}{l}\text { *Primer Set } 1 \text { was generated from a random sequence and contains no homology to human genomic DNA } \\
\text { (13). The sequences of Primer Set } 2 \text { were previously published by Cawthon et al. (14). The 3' complemen- } \\
\text { tary bases of the primer pairs are underlined. A primer-dimer formed by Primer Set } 1 \text { will contain a central } \\
\text { EcoRI site (GAATTC). } \\
\text { **Positive control primers span exon } 13 \text { of ATP12A. } \\
\text { *** Primer } T_{m} \text { was calculated using Applied Biosystems' } T_{m} \text { calculator (http://www6.appliedbiosystems. } \\
\text { com/support/techtools/calc/). }\end{array}$} \\
\hline
\end{tabular}

Table 2. Hot-start polymerases assayed.

\begin{tabular}{|c|c|c|c|c|c|}
\hline Enzyme name* & Company & $\begin{array}{l}\text { Method of enzyme } \\
\text { inactivation }\end{array}$ & $\begin{array}{l}\text { PCR extension } \\
\text { temperature }\end{array}$ & $\begin{array}{c}\text { PCR initial } \\
\text { denaturation time }\end{array}$ & $\begin{array}{l}\text { Batch } \\
\text { number }\end{array}$ \\
\hline $\begin{array}{l}\text { HotMaster Taq DNA } \\
\text { Polymerase }\end{array}$ & $\begin{array}{l}\text { ThermoFisher } \\
\text { Scientific }\end{array}$ & $\begin{array}{l}\text { Derivatized natural affinity } \\
\text { ligand to DNA polymerases }\end{array}$ & $72^{\circ} \mathrm{C}$ & $3 \mathrm{~min}$ & PG177P \\
\hline $\begin{array}{l}\text { TAQ-Ti Heat Activated } \\
\text { DNA Polymerase }\end{array}$ & Fisher Biotec & Antibody-mediated & $72^{\circ} \mathrm{C}$ & $2 \min$ & 211031 \\
\hline $\begin{array}{l}\text { KAPA LongRange } \\
\text { HotStart DNA polymerase }\end{array}$ & $\begin{array}{l}\text { Kapa } \\
\text { Biosystems }\end{array}$ & Antibody-mediated & $68^{\circ} \mathrm{C}$ & $3 \mathrm{~min}$ & KE3502 \\
\hline $\begin{array}{l}\text { KAPA SYBR FAST qPCR } \\
\text { Master Mix }\end{array}$ & $\begin{array}{l}\text { Kapa } \\
\text { Biosystems }\end{array}$ & Antibody-mediated & $72^{\circ} \mathrm{C}$ & $3 \mathrm{~min}$ & KM4108K \\
\hline $\begin{array}{l}\text { Syberfast (for use with the } \\
\text { Roche LightCycler 480) }\end{array}$ & $\begin{array}{l}\text { Kapa } \\
\text { Biosystems }\end{array}$ & Antibody-mediated & $72^{\circ} \mathrm{C}$ & $5 \mathrm{~min}$ & KM4111 \\
\hline MyFi Mix & Bioline & Antibody-mediated & $72^{\circ} \mathrm{C}$ & $1 \mathrm{~min}$ & MFX-111E \\
\hline $\begin{array}{l}\text { KAPA HiFi HotStart } \\
\text { Uracil+ ReadyMix }\end{array}$ & $\begin{array}{l}\text { Kapa } \\
\text { Biosystems }\end{array}$ & Antibody-mediated & $72^{\circ} \mathrm{C}$ & $1 \mathrm{~min}$ & KM2800 \\
\hline $\begin{array}{l}\text { Platinum Green Hot Start } \\
\text { PCR } 2 \times \text { Master Mix }\end{array}$ & Invitrogen & Antibody-mediated & $72^{\circ} \mathrm{C}$ & $2 \min$ & 00319539 \\
\hline $\begin{array}{l}\text { AccuPrime Pfx DNA } \\
\text { Polymerase }\end{array}$ & Invitrogen & Antibody-mediated & $68^{\circ} \mathrm{C}$ & $2 \min$ & 465063 \\
\hline $\begin{array}{l}\text { AccuPrime Taq DNA } \\
\text { Polymerase System }\end{array}$ & Invitrogen & Antibody-mediated & $68^{\circ} \mathrm{C}$ & $2 \min$ & 1196356 \\
\hline $\begin{array}{l}\text { Platinum Taq DNA } \\
\text { Polymerase }\end{array}$ & Invitrogen & Antibody-mediated & $68^{\circ} \mathrm{C}$ & $2 \mathrm{~min}$ & 385786 \\
\hline Pfx50 DNA Polymerase & Invitrogen & $\begin{array}{l}\text { Intrinsic hot-start } \\
\text { capability }\end{array}$ & $68^{\circ} \mathrm{C}$ & $2 \min$ & 878488 \\
\hline $\begin{array}{l}\text { Platinum PCR SuperMix } \\
\text { High Fidelity }\end{array}$ & Invitrogen & Antibody-mediated & $68^{\circ} \mathrm{C}$ & $2 \min$ & 876413 \\
\hline $\begin{array}{l}\text { Hot FIREPol DNA } \\
\text { Polymerase }\end{array}$ & Solis BioDyne & Chemically modified & $72^{\circ} \mathrm{C}$ & $15 \min$ & HF0730 \\
\hline EpiTaq HS & TaKaRa & Antibody-mediated & $72^{\circ} \mathrm{C}$ & $30 \mathrm{~s}$ & A201-1 \\
\hline $\begin{array}{l}\text { PrimeSTAR HS DNA } \\
\text { Polymerase }\end{array}$ & TaKaRa & Antibody-mediated & $72^{\circ} \mathrm{C}$ & $30 \mathrm{~s}$ & N2001EA \\
\hline Ex Taq Hot-Start & TaKaRa & Antibody-mediated & $72^{\circ} \mathrm{C}$ & $30 \mathrm{~s}$ & N6501BA \\
\hline
\end{tabular}

hot-start enzyme. Analysis using Primer Set 1 revealed a primer-dimer for 7 of the polymerases tested, and analysis using Primer Set 2 revealed a primerdimer for 12 of the polymerases tested (Figure 1). Polymerases that produced a primer-dimer with Primer Set 1 also produced primer-dimers using Primer
Set 2, suggesting that Primer Set 2 was more sensitive. The difference in detection sensitivity between primer pairs likely reflects the relative stability of the 3-bp overlap or the $T_{m}$ of each primer, which may have relevance to amplification efficiency during the subsequent PCR cycles. These results 


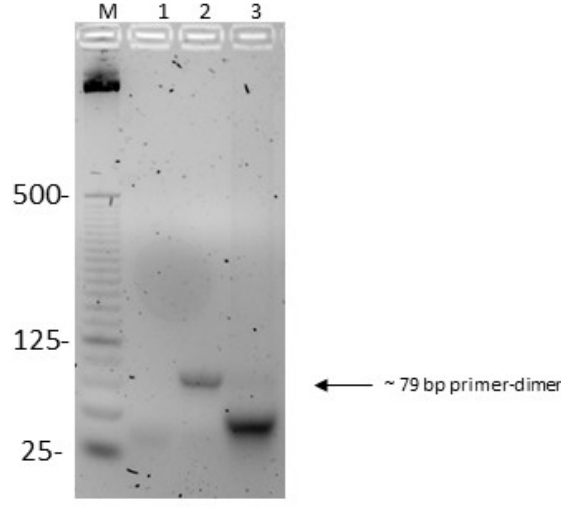

Figure 2. Validation of primer-dimer. Lane 1: "Manual hot-start" PCR; Lane 2: Standard PCR protocol; Lane 3: EcoRI digestion of the remaining PCR product shown in Lane 2. M denotes 25-bp DNA ladder (Invitrogen).

were consistent over multiple assays (data not shown). We have not disclosed the performance of individual enzymes as our findings are based on testing of individual batches of the hot-start DNA polymerases, and we do not know if there is batch-to-batch variation for each manufacturer's hot-start DNA polymerase.

To ensure that the observed amplicon was indeed a primer-dimer, two experiments were performed. First, a manual hot-start PCR was carried out where Taq polymerase was added to aliquots from a PCR master mix at either $95^{\circ} \mathrm{C}$ or room temperature, prior to thermal cycling. The primer-dimer was only apparent when the polymerase was added at room temperature, which was indicative of polymerase activity prior to thermal activation (Figure 2, Lanes 1 and 2). Second, the origin of this band was verified by restriction digestion. The design of Primer Set 1 was such that formation of a true primer-dimer would generate a recognition site for EcoRI (Table 1). Digestion of the PCR product with $E c o R I$ did indeed lead to cleavage (Figure 2, Lane 3), confirming formation of a true primer-dimer.

We found that many commercial enzyme preparations marketed as "hot-start" exhibit polymerase activity prior to thermal activation. PCR applications, particularly in forensic or molecular diagnostic settings, rely on accurate and consistent assays. The failure of many hot-start enzymes to perform as expected could, therefore, have quite profound implications.
Although enzyme suppliers provide evidence of tests for polymerase activity in documents accompanying their products, there is no evidence that they test for polymerase activity prior to thermal activation. We provide here a simple and effective assay that can be used to screen hot-start polymerases for this undesirable property.

\section{Author contributions}

A.S. carried out much of the experimental work and drafted the manuscript. S.A. made initial observations, contributed to experimental work and editing of the manuscript. M.K. contributed to design of the study and editing of the manuscript.

\section{Acknowledgments}

This work was funded by the Carney Centre for Pharmacogenomics and University of Otago.

\section{Competing interests}

The authors declare no competing interests.

\section{References}

1. Mullis, K.B. and F.A. Faloona. 1987. Specific synthesis of DNA in vitro via a polymerasecatalyzed chain reaction. Methods Enzymol. 155:335-350

2. Saiki, R.K., D.H. Gelfand, S. Stoffel, S.J. Scharf, R. Higuchi, G.T. Horn, K.B. Mullis, and H.A. Erlich. 1988. Primerdirected enzymatic amplification of DNA with a thermostable DNA polymerase. Science 239:487-491.

3. B.I. Eisenstein. 1990. The polymerase chain reaction: a new method of using molecular genetics for medical diagnosis. N. Engl. J. Med. 322:178-183.

4. Walsh, P.S., H.A. Erlich, and R. Higuchi. 1992. Preferential PCR amplification of alleles: mechanisms and solutions. PCR Methods Appl. 1:241-250.

5. Nuovo, G.J., F. Gallery, P. MacConnell, J. Becker, and W. Bloch. 1991. An improved technique for the in situ detection of DNA after polymerase chain reaction amplification. Am. J. Pathol. 139:1239-1244.

6. Birch, D.E., L. Kolmodin, J. Wong, G. Zangenberg, and M. Zoccoli. 1996. Simplified hot start PCR. Nature 381:445446 .

7. Chou, Q., M. Russell, D.E. Birch, J. Raymond, and W. Bloch. 1992. Prevention of pre-PCR mis-priming and primer dimerization improves low-copy-number amplifications. Nucleic Acids Res. 20:1717-1723.
8. Kebelmann-Betzing, C., K. Seeger, S. Dragon, G. Schmitt, A. Moricke, T. Schild, G. Henze, and B. Beyermann. 1998. Advantages of a new Taq DNA polymerase in multiplex PCR and time-release PCR. Biotechniques 24:154-158.

9. Kellogg, D.E., I. Rybalkin, S. Chen, N. Mukhamedova, T. Vlasik, P. Siebert, and A. Chenchik. 1994. TaqStart Antibody:" hot start" PCR facilitated by a neutralizing monoclonal antibody directed against Taq DNA polymerase. BioTechniques 16:11341137.

10. Sharkey, D.J., E.R. Scalice, K. Christy, Jr., S.M. Atwood, and J.L. Daiss. 1994. Antibodies as thermolabile switches: high temperature triggering for the polymerase chain reaction. Biotechnology (N Y). 12:506509.

11. Jodczyk, S., J.F. Pearson, A. Aitchison, A.L. Miller, M.B. Hampton, and M.A. Kennedy. 2015. Telomere Length Measurement on the Roche LightCycler 480 Platform. Genet. Test. Mol. Biomarkers 19:63-68.

12. Korbie, D.J. and J.S. Mattick. 2008 Touchdown PCR for increased specificity and sensitivity in PCR amplification. Nat. Protoc. 3:1452-1456

13. Kent, W.J. 2002. BLAT-the BLAST-like alignment tool. Genome Res. 12:656-664.

14. Cawthon, R.M. 2009. Telomere length measurement by a novel monochrome multiplex quantitative PCR method. Nucleic Acids Res. 37:e21.

Aaron J. Stevens*, Sarah Appleby*, and Martin A. Kennedy

\section{Gene Structure and Function \\ Laboratory, Department of \\ Pathology, University of Otago, \\ Christchurch, New Zealand}

${ }^{*}$ A.J.S. and S.A. contributed equally to this work.

BioTechniques 61:293-296 (December 2016)

doi 10.2144/000114481

Keywords: PCR; hot-start polymerase; primer-dimer; polymerase activity; quality control; DNA amplification

Received 23 June 2016; accepted 15 August 2016.

Address correspondence to Martin A. Kennedy, Department of Pathology \& Carney Centre for Pharmacogenomics, University of Otago, Christchurch, PO Box 4345, Christchurch, New Zealand. E-mail: martin.kennedy@otago.ac.nz

To purchase reprints of this article, contact: biotechniques@fosterprinting.com 